International Journal of Social Science and Economic Research

ISSN: 2455-8834

Volume:05, Issue:10 "October 2020"

\title{
POLICY REPORT INDIAN RAILWAYS: CHILD RESCUE CAMPAIGN
}

\author{
Kevin Gabriel \\ Department of Politics, Master of Public Administration \\ Academic Year: 2018/2019, University of York (UK)
}

DOI: 10.46609/IJSSER.2020.v05i10.032 URL: https://doi.org/10.46609/IJSSER.2020.v05i10.032

\begin{abstract}
In 2013, the Delhi High Court had instructed three ministries namely the National Commission for Protection for Child Rights (NCPCR), Ministry of Women and Child Development (MWCD) and Railways Ministry for implementing the Standard Operating Procedure (SOP) to protect the vulnerable children coming in contact with the Railways. The following essay uses the Multiple Streams Approach (MSA) framework, to analyze the agenda setting process in the shift of child protection responsibilities onto a transport ministry, i.e the Indian Railways and provides insight into the work being done for the protection of children. This is the first time the MSA framework has been used to analyze a social policy in a developing country.
\end{abstract}

\section{Introduction}

It is quite early in the morning, the hustle bustle of the platform has died down. Saroo a 5 year old boy awaits the return of his elder brother Guddu, who is out performing odd jobs such as picking litter and empty plastic bottles at the railway platform in order to fend for his family. After a nap on the platform bench, Saroo is awoken by a long lasting silent eeriness of the platform, his brother who had promised to be back before the break of dawn was still missing. Curiosity gets the better of him, unheeding his elder brother's command of staying put, Saroo heads out to find him. He embarks on a stationed train thinking his brother might be in it cleaning the coaches. However the wee hours of the morning take a toll on his feeble body and soon he falls prey to the warm embrace of sleep on a berth in one of the coaches. Destiny had planned something else for this little boy, instead of being reunited with his brother, he wakes up to find that the train is on the move. After a few days it arrives in the metropolitan city of Kolkata. which is about $1600 \mathrm{kms}$ away from Saroo's hometown in the district of Khandwa (Madhya Pradesh). He thus is lost and finds himself far away from home. 


\section{International Journal of Social Science and Economic Research}

ISSN: $2455-8834$

Volume:05, Issue:10 "October 2020"

India is diverse in its culture, with languages and dialects changing across the different regions of the country. Saroo soon finds himself in an alien environment,with an overwhelming crowd present at the Kolkata station, he frantically tries finding help. However language proved to be a barrier, people could barely understand him. This combined with his disheveled state of grooming made him invisible to the railway officials and various passerby. Just like an undesirable, he had to vacate the stations premises in search for help. This is the opening few minutes of the BAFTA winning movie Lion, based on the autobiography of Saroo Brierley, A Long Way Home. Saroo eventually had luck smile upon him as he gets adopted by caring family in Tasmania, Australia. However, most of the runaways or cast aways found on the Railway Stations are not as lucky as him.

Just like Saroo, thousands of children end up on the railway stations of the country each year due to varied circumstances.

Clarke and Stewart (1997) had coined the term 'wicked issues 'for issues which do not have just one cause and response, e.g. climate change. These issues become more complex as often there is no clarity on the potential responses and it is difficult to address them due to limited budget and large interconnected nature of these problems with other problems. Often a capacity to think outside and work across organizational boundaries needs to be developed. A social policy on child protection involves multiple organizations and actors involved, each with their own unique skill sets which help them to address the problem.

This paper will examine the agenda setting process using the Multiple Streams framework (MSA) developed by John Kingdon, its application in a developing country revolving around the unique initiative of the Indian Railways, a policy called the 'Standard Operating Procedure (SOP) for Railways to ensure Care and Protection of Children in contact with Railways. '

This essay seeks to assess the extent to which the MSA can help us understand how the wicked issue of child protection for railway reached the government's agenda and how a transportation ministry like the Indian Railways got involved in solving the problem.. The problem definition in the initial phases was limited to rehabilitating runaway children with their families. When the problem of trafficking was realised there was involvement of three ministries to solve the problem and this lead to a policy window opening up. The essay finds that there was no significant political policy entrepreneur who coupled the three streams, but instead it was an activist who approached the judicial system to gain the necessary help. The paper is divided into 6 sections. The first section contains the literature review which would be explaining the Multiple Streams Approach (MSA) and its applicability. The second section contains the background associated with the case study. The third section looks at the applicability of the 


\section{International Journal of Social Science and Economic Research}

ISSN: $2455-8834$

Volume:05, Issue:10 "October 2020"

MSA in the case study. This section would be followed up with the discussion on the findings from the research. The fifth section provides some further insights into the policy. This section would be followed up with the conclusion.

\section{Literature Review}

In his now-famous work, John Kingdon (1995) proposed a theoretical response to two questions often raised by those studying public policy agenda-setting: "What determines the emergence of some ideas over others? Why are certain ideas used by governments to formulate public policies, and not others?" (Ridde, 2002). Kingdon describes how the separate streams of problems, solutions and politics converge to move an issue onto the public policy agenda toward potential governmental action. Kingdon argues that policy making does not proceed neatly in stages or steps but rather how these separate streams flow and converge at a later point in time. Kingdon's research moves beyond the heuristic stages which is advocated by scholars especially system theorists.

This section of the paper would be providing an overview of Kingdon's multiple streams model $(1984,1995,2003)$ which found its origins in the book titled Agendas, Alternatives and Public Policy. Developed along the lines of Garbage Can theory which was developed by Cohen et al (1972),

The Garbage Can Theory found its origins in understanding how organizations like Universities work. It can be described as having 3 general properties which are :-

1. Problematic Preferences could be understood as situation where there is no clear definition of preferences. In case of federal agencies as defined by Kingdon, political actors fail to define their goals. Even when they do define their preferences conflict in definition amongst the various actors hence leading to inconsistency. Cohen et al (1972) define organization as "a loose collection of ideas than [Organization] as a coherent structure; it discovers preferences through action more than it acts on the basis of preferences." (pg.1).

2. Unclear Technology occurs in an organization when the people may know their work and role but only have a rudimentary and fragmentary understanding of what, why and how their job is to be done and how it contributes to overall scenario.

3. Fluid Participation occurs when participants keep drifting in and out of decision making boundaries, their time and effort devoted to the organization is variable to the subject in discussion. 


\section{International Journal of Social Science and Economic Research}

ISSN: $2455-8834$

Volume:05, Issue:10 "October 2020"

In such organizations there are 4 separate streams running, which are :-

1. Problems are the concern of people inside and outside the organization arising due to issues such as lifestyle, money, ideology, mass media etc. All these require attention.

2. Solutions are the required answer to the problems.

3. Participants have the free will to enter the arena to participate in problem solving decision.

All these 4 streams flow separately and unrelated to each other. Choice opportunity in such organizations can be thought of as a garbage can where participants generate problems and solutions and dump them in the can, these solutions are to be used in case a problem arises. People do not set about to solve problems just because the situation dictates them to do so, they do so because they have an ulterior motive attached to it (such as promotion, emotional appeal etc). Hence as Cohen et al (1972) say, this kind of organization "is a collection of choices looking for problems, issues and feelings looking for decision situations in which they might be aired, solutions looking for issues to which they might be the answer and decision maker looking for work" (pg.2).

The Multiple stream approach (MSA) challenges the notion that unlike the Garbage can theory which emphasizes that organizations are like "organized anarchies" facing the problems of problematic preferences, unclear technology and fluid participation; policy making takes place in a rational and systematic manner. (Kingdon, 2003). The MSA could conceivably be extended to cover the entire process of policy making at various levels of government, it is examined here only in its capacity to explain policy formation.

This paper would discuss the model's application, its existing limitations and usefulness discussed by various authors to explain the agenda setting process of a policy.

MSA is useful for explaining how a policy was formulated or why an existing policy undergoes changes.

Before we divulge into the details of Multiple streams let us examine what is meant by the term 'policy'.

\section{POLICY}




\section{International Journal of Social Science and Economic Research}

ISSN: $2455-8834$

Volume:05, Issue:10 "October 2020"

Hogwood and Gunn (1984) define policy as specific instructions, an expression of intent (e.g. we will provide free internet for all), specific proposals, decisions taken by the government and their formal authorizartion, a programme or legislations passed, or an event which is formed by series of decisions. There has been speculation on the term public policy and what it actually means. Cairney (2011) suggest that understanding policy measure is more of an "art than science" (p.24). In short, it is safe to say that any rule formulated by the government or judicial system are all covered under the umbrella term 'policy'.

\section{AGENDA SETTING}

Knill and Tosun (2012) in their book Public Policy- A New Introduction link the understanding of the term agenda setting with problem definition. Problem definition is about making issues public and turning them into problems that are received as important. As soon as a problem is identified in an environment, various actors have an opportunity to rectify it. However, the catch is in the definition of the problem which is subjected to the various actors and their interests and resources involved in it. According to Zahariadas and Travis (2002) people often define problems by 'letting their values and beliefs guide their decisions by placing subject under one category rather than another '(pg.496). This might lead to the problem of people thinking a problem exists, however their view on how it came about and how to deal with it might vary contextually. In this process various solutions are generated. However just like a soup not all solutions stay afloat and only a select few are chosen as a response to the problem.

Coming back to the topic of MSA, which helps understanding the process by which agendas are set and its alternatives are specified ( Kingdom, 2003). For a policy to be set it undergoes 3 processes which are: problems, policies and politics.

Problems might be triggered by a crisis or prominent events, such as the rising levels of pollution causing respiratory problem among the masses or consumption of excessive alcohol causing the country's youth to spiral into health and household problems. Such problems along with their indicators such as rise in death rates, disease rates, mortality rates etc are often noticed by the governmental agencies who then can act upon them. "Indicators are used to assess the magnitude of the condition and to discern changes in a condition" (Kingdon, 2003). Studies conducted by governmental researchers for academicians also help in bringing light to such issues (Kingdon, 2003). Sometimes, some issues become a prominent item on the agenda due to a policy makers having personal experience with that subject (ibid, p.96). Often feedback channels such as media channels and public deliberations help to shed light on these problems (Brunner, 2008). Hence there are three mechanisms identified in the literature which sheds a light on problems Indicators, Events and Feedback channels. 


\section{International Journal of Social Science and Economic Research}

ISSN: $2455-8834$

Volume:05, Issue:10 "October 2020"

"In the policy stream, policy communities generate alternative policy proposals to alleviate identified problems, and proposals advance or fail based on their technical feasibility, their value acceptability, and how well they anticipate constraints." (McMillin, 2014, p.278). These policy communities are composed of specialists in a given policy area. Constant interaction amongst this community helps them to know each other's ideas, research, proposals and at the same time helps them to improve upon their own work. (Kingdon, 2003). This stream functions independently from the politics stream and is not "effected by the changes of administration and pressures from legislators 'constituencies" (ibid, p.117).

In the political stream, compromise and negotiation during an open policy window lead to policy acceptance depending on the national mood, the activity of advocacy groups, and the political circumstances of jurisdiction and electoral turnover "(McMillin, 2014, p.278). "It is composed of such factors of swings of national mood, election results, changes of administration, changes of ideological or partisan distributions in Congress and interest group pressure campaigns" (Kingdon, 2003, p.162).

It is believed that politicians are able to sense the national mood from the various sources of communications that come to them like mail, telephone, trips home etc. On the other hand, non elected officials take the reading of the national mood through politicians (Kingdon, 2003).

Integration of these 3 processes opens a 'policy window', during this time the topic is under high attention from the masses, solutions for the policy exist and policymakers have the motive and opportunity to select it. (Cairney and Zahariadis, 2016, p.1; Kingdon, 2003). These policy windows open infrequently and do not stay open for long. Hence, the participants have to make sure that they are able to take an advantage of the opportunity otherwise they have to wait for another window to open up. These participants are also known as policy entrepreneurs who are known to seize windows of opportunity to couple a problem stream with a political stream. "Policy entrepreneurs are regarded as key actors in the agenda-setting process that advocate solutions, broker communication, and build or sustain coalitions to couple or join together the three streams" (Mintrom and Norman, 2009). Without the presence of this entrepreneur, the linking of the streams might not take place. A policy entrepreneur can be thought as someone who brokers people and ideas, it involves recombination of existing ideas and selling them under a "new brand name". However "they are required to couple solutions to the problem, problems to the political forces and political forces to the policy proposal" and make sure that they are present at the right place at the right time (Kingdon, 2003). "Agendas are not first set and then the alternatives generated; instead, alternatives must be advocated for a long period before a short run opportunity presents itself on an agenda." (Kingdon, 2003) . 
The MSA is different from the other lenses as it does not view the participants involved in policy making solely as rationalists or constructivists. Rationalists assume that policymakers are utility maximisers while constructivists conceive of policy making as driven by persuasion and the social construction of identity and meaning (Zahariadis, 2003). The Multiple stream uncovers rather than assume rationality.The MSA helps the political actors to determine which solutions are good enough. Policy makers make a decision to solve the problem-solution sequence with the information presented, which is correlated with the way it is presented and processed. Policy analysts are often limited by using single lenses while analysing policy questions from multiple perspectives. The MSA although being a singe lens, provides greater overall explanation because it explains more accurately a greater number of occurrences (Zahariadis, 2007).

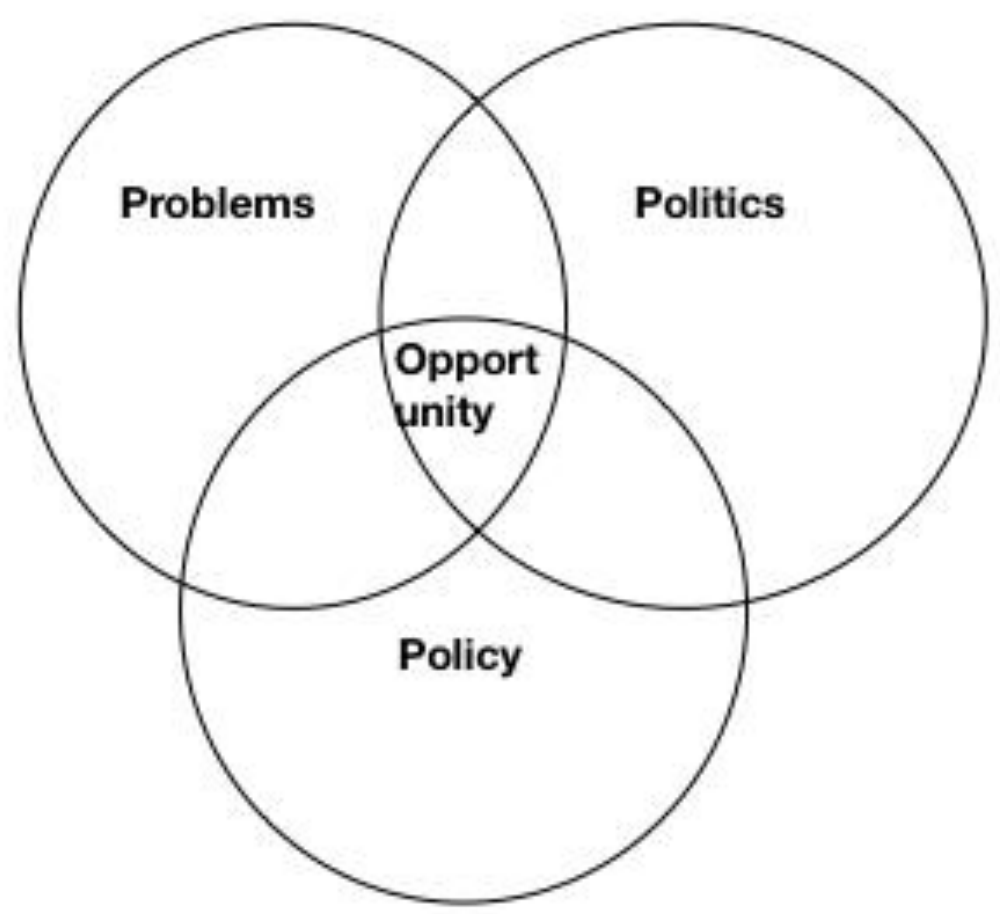

Combination of the three streams opening up an opportunity window

However despite its extensive application due to the frameworks generalisability it doesface criticism from time to time. The MSA found its origins in the American presidential system and thereby is limited to the politics of the United States (Demers and Leimux, 1998, Howlett and Ramesh, 1995). 


\section{International Journal of Social Science and Economic Research}

ISSN: $2455-8834$

Volume:05, Issue:10 "October 2020"

Exworthy et al $(2002,2004)$ have detailed it out in their work on how the MSA just focuses on the "Big Windows" of opportunity and ignores the "little windows", hence it focuses on policies which have a national affect, while the framework has rarely been applied to the local level. In their paper (2004), they explain how Kingdon's study is just limited to how healthcare and transportation issues reached the federal agenda in the US. However the model fails to examine the "little windows" at the local level while focusing on the "big windows 'at the central level. Using Kingdon's framework of policy stream they explain how issues of health inequalities get onto the political agenda nationally and locally and how it is implemented. This is shown in a case study done by them in the year 2002. In the article they use the term "health inequalities" to refer to inequalities in health status and healthcare. These health inequalities were supposed to be solved with collaboration amongst the central government and the local government. Powell et al (2001), describe this as joined up government (JUG) with the government emphasis on interdepartmental and interagency working. The local government had been working for a long time to reduce health inequalities amongst the population before the central government finally noticed the problem after several years to implement a solution to the problem on a grand scale. The article explains on how the expectations of the local government were being dashed in the Westminster. The local government took the responsibility of solving health inequalities much more seriously than the central government. "The issue of health inequalities was on the agenda but its position on agendas was variable and at risk of relegation by seemingly more pressing priorities." (Exworthy et al,2002). The national and local expectations on how to solve health inequalities was different with central government having problems with the local government arising due to poor intergovernmental relations, an underdeveloped JUG, poor local partnerships and low performance management. This led to the "Big window" of solution to the problem of health inequalities being closed by the central government, while the "little window" proposed by the local government still remaining open. At the end the paper helped realise even though the streams had converged to open the policy, it was only realised in the case when the central government was involved.

One another criticism faced by the framework is that most scenarios with the MSA are just limited to the developed countries and empirical studies have been limited to Canada, Great Britain, France and Germany. (Brunner, 2008). Most of the literature on the MSA has been based on case studies involving health, climate or transportation policies. According to the authors knowledge there has not been case study explained based on child protection policy using the MSA framework. 


\section{International Journal of Social Science and Economic Research}

ISSN: 2455-8834

Volume:05, Issue:10 "October 2020"

\section{Background}

According to the data published by the National Crime Records Bureau in their report Crime in India- Statistics 2016, the total number of crimes against children is a whopping 106958, while about 94172 crimes were recorded in the year 2015, indicating an alarming increase by $12 \%$. Kidnapping and abduction of children were the highest registered category of crime against children, accounting for more than half of all crimes in 2016. Cases registered under Protection of Children from Sexual Offences Act, 2012 (POCSO) were reported as high as 34.4\%.Rape is also a big category of crime against children amounting to more than $18 \%$ of all crimes against children.

Kidnapping and abduction cases of children more than often qualify as cases of child trafficking. In the following table extracted from the published records of National Crime Records Bureau from 2003 to 2013, a large number of children were kidnapped or abducted mostly for the purpose of marriage or illicit sexual intercourse. The number of such cases are on the high due to factors such as increase in population, economic disparity, urbanization, better connectivity, penetration of internet and information technology.

\section{KIdnapping And Abduction Cases That Quallfy As Cases Of Chlld Trafflcking}

\begin{tabular}{|c|c|c|c|c|c|c|c|c|c|c|c|}
\hline $\begin{array}{c}\text { Year } / \vec{\rightarrow} \\
\downarrow \text { Purpose of } \\
\text { kidnapping and } \\
\text { abduction }\end{array}$ & 2003 & 2004 & 2005 & 2006 & 2007 & 2008 & 2009 & 2010 & 2011 & 2012 & 2013 \\
\hline Adoption & 21 & 15 & 41 & 23 & 36 & 34 & 44 & 37 & 62 & 46 & 111 \\
\hline Begring & 6 & 20 & 19 & 24 & 13 & 17 & 30 & 34 & 45 & 29 & 44 \\
\hline Illicit intercourse & 383 & 414 & 501 & 676 & 649 & 825 & 765 & 749 & 1373 & 1113 & 2910 \\
\hline Marriage & 1369 & 1593 & 1693 & 2621 & 3224 & 4003 & 4177 & 5193 & 8409 & 10572 & 14242 \\
\hline Prostitution & 58 & 101 & 117 & 148 & 130 & 130 & 165 & 93 & 137 & 143 & 60 \\
\hline $\begin{array}{c}\text { Selling body } \\
\text { Parts }\end{array}$ & 0 & 1 & 3 & 1 & 0 & 0 & 0 & 0 & 0 & 0 & 0 \\
\hline Uniawful activity & 109 & 92 & 58 & 30 & 84 & 138 & 219 & 160 & 222 & 270 & 382 \\
\hline Slavery & 6 & 16 & 4 & 15 & 35 & 32 & 49 & 26 & 24 & 5 & 19 \\
\hline Sale & 13 & 13 & 9 & 11 & 12 & 14 & 39 & 51 & 166 & 54 & 49 \\
\hline SUM TOTAL & 1965 & 2265 & 2445 & 3549 & 4183 & 5193 & 5488 & 6343 & 10,438 & 12,232 & 17,817 \\
\hline
\end{tabular}




\section{International Journal of Social Science and Economic Research}

ISSN: $2455-8834$

Volume:05, Issue:10 "October 2020"

With privatisation sweeping across the globe, most state enterprises are going into the hands of private enterprises. Railways which has been a state government commodity in most of the countries such as the UK, which has opened it up to private players ever since 1991 after the EU initiative. The security of the railway trains and its premises is in the hands of private agencies or the local police.

Deregulation of the Indian Railways was never an option for the Indian Government due to its vast network and existing quotas and subsidies for the masses. However, with thousands of trains plying across the nation daily with tens thousand of people, security and risk to passengers often becomes an issue, not just in the trains but the platforms as well. Security measures in such circumstances falls in hands of the Government. Over a considerable period of time one neglected subset of these passengers have been vulnerable or runaway children. These children are occasionally noticed travelling in trains or living in and around railway stations and prone to fall in the company of wrong hands. As per the Indian Railway Year Book 2017-18 published by the Directorate of Statistics \& Economics, Ministry of Railways (Railway Board) there are 7,318 Railway Stations in India. According to estimated data presented by the Indian Railways, in every 5 minutes, an unaccompanied child arrives at a Railway platform in India. But one is made to wonder, whether a state organisation like the Indian Railways is capable of dealing with the social issue of these runaway children, or should it be left in the hands of ngos and other state departments dealing with issues of human rights.

According to the Bibek Debroy Committee which was constituted by the Railway Board for mobilization of resources for major projects and restructuring of Railway Board and Railway Ministry, highlights that the Railways should cut down its focus on non focus areas. These include running of hospitals, schools, housing projects etc. One of the key element area the report focused on was shutting down the Railway Protection Force (RPF) and Railway Protection Special Force (RPSF). The committee believed the task of protection and security rests with the State Police forces or it should be outsourced to a third party. The key point of this suggestion was to reduce the size of monolithic organization and improve its efficiency. (Mishra, 2015; The Economic Times, 2015). However the RPF has been at the forefront of rescue of runaway and trafficked children found on railway premises and trains.

They are the most active component of Child Protection Committees and play a vital role in rescuing trafficked children and handing them over to either legitimate guardians, or authorized NGOs, working in this field. During the year, 2013 - 4658 minor children, in the year 2014 4448, and 2015 - 7044 children were rescued due to the efforts of RPF personnel. The campaign called "Operation Smile-II" launched by MHA from 1st January, to 31st January, 2016 was carried out by RPF as well. (South Asian Government News, 2015; Indian Government News, 


\section{International Journal of Social Science and Economic Research}

ISSN: $2455-8834$

Volume:05, Issue:10 "October 2020"

2017). Thus one cannot overlook the role the Railway security forces play in ensuring the welfare of the society.

Coming to the question; Who are these 'runaway children 'and Why do they land up at the railway stations in India ? The answer lies in the existing preconceived psychological interpretation of Railway stations and railway coaches as "gateways" to a better life. This has been demonstrated time and again through various channels, especially Bollywood. Taking an example of another movie, Slumdog Millionaire, the lead character Jamal Malik along with his brother Salim travel across the country, as full time train residents. They fend for themselves by selling trinkets and snacks on the train, and often resorting to stealing food to satisfy their hunger pangs. Their journey is one filled with adventure and thrill, with their destination ending up at "heaven" which is apparently the Taj Mahal; a perfect symbolism applied to depict the monument's beauty and allegory depicting the children's journey to a new found promising land.

However, the influence of Bollywood and movies alone aren't enough to motivate a child to runaway. Steinberg (2012) in his article explains how children in India stake claims with their bodies to the railway space, it talks about the "implications of the active use by Indian "platform children" of railway space in the context of ideologies about (and histories of) that space, ideologies and histories that shape their interaction with it".

Ever since a young age, kids are familiarised with environment of the Railway Station and are often working odd jobs like selling tea, food items and trinkets to earn some additional money for the family. This exposure to the rail space enables the potential for movement to be naturalised. Cultural upbringing plays a very important role in the thought process of most of the runaway juveniles. In an article by Townsend (2017), Interview with two runaway kids from the state of Bengal, indicated that Railway Station for them was equated for adventure and discovery, and their rite of passage on becoming men was to "roam" in places where they hadn't been before (This could be equated to a young American adult travelling abroad for his/her Eurotrip; However in this case the environment is not safe for children). Street children nestling in or near the railway station often benefit due to the facilities of free washrooms. In most Indian Railway stations you would find a tube well or hand pump installed on the premises which often solves the problem of bathing for these children. The idea of always being "mobile" and able to move and escape from authorities, ability to pack up leave and settle in a new place, further on adds in making Railway stations a lucrative option.

Most of the runaway children belong to the lower income class of the country. A study conducted on street and runaway children in the city of Jaipur revealed that most of them belonged to the lower income rural class of the economy, opportunities of a better life lead most 


\section{International Journal of Social Science and Economic Research}

ISSN: $2455-8834$

Volume:05, Issue:10 "October 2020"

of the children runaway to a) escape the domestic problems at home, b) lure of a better life, c) to earn for the family's and individuals survival. (Townsend, 2017; Steinebrg, 2012; Raval et al, 2010 ; Mathur, 2009). Hunger is also one of the main cause of children running away from poverty stricken states such as Bihar, Orissa and Rajasthan. Most of these children end up getting trafficked.

'It is hunger and violence which are forcing children to run away from home and find themselves in railway stations and from there on to rich homes as domestic help, or as sex slaves and camel drivers in distant shores or as child labour in dhabas, run- down shops and hazardous industries where life is cheap, and death a release. '(Roy, 2016).

Similarly a Study on 'Child Reunification Processes in India' conducted by Railway Children, an NGO has revealed that almost half of the children leave their home due to fear of punishment, feeling neglected or lonely and without having perceived goal or destination. These children who use Railway as a mode for travel are at the risk of becoming vulnerable to crime and are in need of care and protection.

Most of the runaway children consists of boys on the platform, there are runaway girls too, but their length of time on the streets is relatively much shorter. Girls unlike the boys are always at the risk of being immediately recruited into formal prostitution before or upon arrival into the city. (Steinberg, 2012). In a research conducted by Raval et al (2010) on runaway adolescent girls revealed that the end result for most of the girls was something which the Bollywood movies wouldn't consider a "Happy ending". The article talks about most of the girl's runaway to pursue their love interests. Research methods involved interviews with these women in a Women's institution in Gujarat, India. They narrate their lives on how the situation came about which led them to leave their homes in search of a better life. The constant threats at home, danger to their lives and the fear of being rejected by their community often leads these girls to run away. Domestic violence is a major issue which is prevailing in their stories. However, the author talks about a double bind; even though the situation at home for these girls isn't safe, so is the life after they run away. Most of these women become victims of prostitution or are rejected on returning home after running away due to long impending court cases filed against them by their family members which further prevent these girls from getting married. Hence even if they run, they are doomed to a scenario which is unfortunate.

The following section applies the multiple streams approach to the social policy in the developing country of India. It shall be investigated how the Kingdon's approach explain the drivers of policy change in the case study. 


\section{International Journal of Social Science and Economic Research}

ISSN: $2455-8834$

Volume:05, Issue:10 "October 2020"

\section{Procedure}

This study utilised interviews with two high ranking senior officials from the Railway Protection Force (RPF) who provided valuable insight about the SOP being implemented and the situation before its implementation. The interviews consisted of a series of questions which revolved around the topic of agenda setting. Questions revolved around assessing the situation before the implementation of the SOP, the actors involved in the process, conflict amongst the actors (if present), help from additional sources, political actors involved in the process and belief in the ability of the Railways to solve the problem. All interviews were conducted in English and transcribed by the researcher.

The two senior officials who were interviewed would be identified as Individual $\mathrm{X}$ and Individual Y. The results of the interview would be synthesised with the MSA framework in explaining how the policy came into existence. Other than this there was extensive reliance on secondary data which involved looking at existing research papers, unpublished documents and letters of the Indian railways, rules and legislatures, newspaper reports and statistical data on street/ runaway children.

\section{Using Multiple Streams in the Case Study Problem Stream}

Kingdom (2003) points that each stream follows independently of each other, the flexibility of the MSA allows for the relationship between the problem and policy streams to be either 'consequential '(the policy is formulated in response to the problem) or 'doctrinal '(the problem is sought out in response to an ideologically driven policy agenda) (White, 2015). In our case study the problem was identified first.

As explained in the paragraph above, the entire structure and cultural linkage of the railway premises provide a suitable environment for Runaway children, it is a perfect environment of blending in amongst the crowd. However it is not free of problems. The problems in our case study could be understood better if it is broken down into two components.

\section{Self Harm caused by children}

\section{Trafficking}

We would now examine the first problem.

In an interview with Individual $X$, it was revealed that most of these children he interacted with during his tenure (1996-97) at the New Delhi Railway Station were involved in various unscrupulous activities such as stealing, indulging in excessive violence, consuming cheap drugs 


\section{International Journal of Social Science and Economic Research}

ISSN: $2455-8834$

Volume:05, Issue:10 "October 2020"

and inhaling intoxicating glues such as dendrite, fevicol, sunfix, etc. Even today, the problem of consuming cheap drugs especially cheap inhalants is still high and persistent. Hamza Khan (2015) in his article talks about how most of these kids on the platform are addicted to sniffing glue to escape reality for a brief amount of time. Substance abuse takes a huge chunk of earnings from these kids. According to a study conducted on street and runaway children in Delhi indicated that more than half $(57.45 \%)$ had indulged in substance abuse, out of which consumption of nicotine was the highest $(44.5 \%)$ followed by inhalants $(24.3 \%)$ (Pagrae et al, 2004). This substance abuse is often a cause of death for these children as they often roam the tracks collecting garbage and plastic bottles in an intoxicated state, thus impairing their senses and causing accidents resulting in mutilations or in some cases even deaths (Jayant Gupta, 2011; Steinberg, 2012). Most of these kids become mules transporting drugs such as Ganja (Marijuana) for criminal operations.

Despite the constitutional laws in place such as the Child Labour (Prohibition and Regulation) Act (CLPRA) 1986 which defines child as a person who has not completed 14 years of age and prohibits engagement of children in certain employments and to regulate the conditions of work of children in certain other employments. A walk through the railway station weaves a different tale altogether, you can see children rummaging through the garbage, searching for hidden treasure. Hamza Khan (2015) in his report points out how these kids go about collecting empty water bottles, refilling them with tap water, resealing them with tape and reselling them. The ones which cannot be resold are collected and sold to the recycling plant. He estimates that they earn an approximate of INR 200 per day. These children are not formally employed by an employer, but work to sustain their living which is often done under an elder child of the group. (Steinberg, 2012; Mathur, 2009).

Steinberg (2012) explains how these children stake claim to the resources of the railway station, just like a citizen gaining citizenship and using the state's resources. As per individual Y, the railways in this scenario tries its best to deter the practice of children working on the platform by employing agencies for the cleanup process in big stations. However, the practice remains unchecked in various small stations functioning throughout the country. There is no official data present on the number of children found working on the railway platforms but as per the 2011 census the total number of children working as 'marginal worker 'or 'main worker', between the age group of $5-14$ is $3.9 \%$ of the total child population which is equivalent to 10.1 million children. In addition to this there are 42.7 million children out of school (ILO, 2017). This puts these children in a vicious child labour cycle whereby even their progeny suffers on the account of remaining uneducated, thereby augmenting towards poverty, in a never ending loop (Chopra, 2015). 


\section{International Journal of Social Science and Economic Research}

ISSN: $2455-8834$

Volume:05, Issue:10 "October 2020"

In Kingdon's model, for a policy to reach the central agenda it must gain enough momentum by gaining popularity amongst the masses (2003). Back in the year 2001, Individual X realised the problem of increasing number of runaway children arriving at the railway platforms. During his posting in Malda (West Bengal), he introduced a number of programs in which the RPF interacted with the children, taught them basic arithmetic and the local language, improved discipline amongst them, provided them with food and clothing, soap and bath water for sanitation. The idea of 'collection point 'was generated, where newcomer children would be segregated, and the process of reuniting them with their families would be initiated as soon as possible. However it was a challenge for him and his team due to limitation of resources, limitations of reach and demands of their profession.

However soon the program started to come into the limelight, it received a positive response from not just the children but started getting appreciated in Bengali/English media channels frequently.

Soon NGOs started steeping up in helping them in their endeavours, an NGO named Muktangan became partners with this program and started receiving funding from an big international organization called the Railway Children which was set up in the United Kingdom. By 2004, the Week Magazine had covered the model program extensively and UNICEF covered the model in a separate chapter in the annual document for children. There was coverage by international and local media from time to time, indicating that matter had gained importance on the national level. The Director General RPF (then), Mr. Pandey, was impressed with the work being carried that he instructed that the model be replicated in other important Railway Stations, with this decision the official involvement of the RPF organization began in protection of the vulnerable children (Interview). The model of the Malda station was replicated throughout several stations especially the big ones such as Mughalsarai, Sealdah and Patna. The involvement of various NGOs throughout the country helped realise the urgency of children being protected against drug and sexual abuse, which soon got the attention of the Women and Child Development Ministry. (Interview). Feedback comes to governmental officials more informally, with sources like media advocating their cause, information soon spreads through word of mouth communication.

A total of approximately 1800 children were outreached out through Muktangan intervention during the years 2003 to 2010 (Vital1, 2014). However at this point of time the Railways problem definition and solution to the problem was to reduce the number of runaway children at the platforms and help reunite runaway children with their families. This however changed with an inclusion of an additional problem gaining significance over the past few years.

The UNHRC had placed India in the Tier 2 list for elimination of human trafficking, stating that the government had demonstrated increasing efforts to the previous period, with clear conceptual 


\section{International Journal of Social Science and Economic Research}

ISSN: 2455-8834

Volume:05, Issue:10 "October 2020"

indicators and internationally established methodologies and standards, however data regarding the change is not produced by the country on a regular basis. (US Department of State, 2018).

In the year 2009, the Ministry of Home Affairs (India) had issued a non-bonding directive advising state officials to use Standard Operating Procedures (SOPs) for proactive victim identification and referral to protection services (US Department of State, 2018). Since it was a non binding directive, it was hard to ascertain which state governments had actually implemented these SOPs. There was high reliance on NGOs on identification of potential victims. In the year 2017, The National Human Rights Commission (NHRC) had created and published SOPs for combating human trafficking. These SOPs included information on the 'definition of trafficking, myths and misconceptions about trafficking, a screening tool to help identify potential victims, steps to rescue a victim including providing immediate care and support to the victim, and information on rehabilitation programs and restitution '(US Department of State, 2018).

Addressing the second problem which is trafficking, which has emerged as a 'low risk high return well organised criminal activity 'in India (Chopra, 2015). Minors being a part of the sex industry is nothing new in India with origins being found in the cultural, traditions and religious practices of various tribes such as Devadasi, Jogini or Bedia tribe of Rajasthan which pledges girls into life long prostitution (Chopra, 2015; Nair, 2003). Human trafficking in India is at a rampant rise, in 2015 a total of 6877 cases of human trafficking were registered, out of which 3,087 cases were procuration of minor girls and 111 cases of selling minor girls to prostitution (UNODC,2018; NCRB, 2016). Indian Railways, being the cheapest mode of travel across the country is often used by the criminals to carry trafficked people from one place to another.

Soroka's (2002) study of agenda setting of the mass media explains that governmental issues such as social policies which are 'sensational issues 'are less connected with the daily lives of the population but still have tangible effects for most of the population are often marked by dramatic events which draw massive media attention. This correlates with Kingdom's argument that events or crises often help realise problems

In the past, several cases being reported from the states of Goa and Kerala such as the infamous case of Freddy Peats highlighting human trafficking of minors taking place at an unprecedented level and how the country has become a hotbed for child sex tourism (Chopra, 2015; Nair, 2003).

In the year 2006, the infamous case of 'Nithari killings 'made the national headlines, a spine chilling case of abduction, rape, murders and necrophilia involving 16 children. (LiveMint, 2017). These cases helped shed light on the vulnerability of the children and the danger posed to them by the society. We have seen mass mobilisation when there is a strong opinion on topics 


\section{International Journal of Social Science and Economic Research}

ISSN: $2455-8834$

Volume:05, Issue:10 "October 2020"

such as rape, farmers suicide and injustice against women, demanding government action. However issues such as child protection, especially those whose voices never get heard, media coverage does fall short at times (Faleiro,2017). At times like these, when an issue of child violence or abuse surfaces, the focus of mass population and the media is generally fixed on punishing the perpetrator rather than addressing the main cause of the problem. Before the implementation of the SOP, individual X had explained in his interview the attitude of the RPF and Railway staff working on the platform towards the runaway children. The presence of these children on the platform was seen as a menace, the only response by the officials was to remove them from the platform. Interaction with local shopkeepers at the Mughal Sarai Station, indicate that most of these kids are referred to as "gadais", a Sanskrit term which roughly translates into 'lower caste'. (Hamza Khan, 2015). The cultural norm which is accepted by a vast majority is that children from the lower castes are born to work (Chopra, 2015). With limited data available it is hard to ascertain the impact the media made on the population to pressurise the government into taking action. It would be fallacious to say that the media was not able to gain momentum at all for the vulnerable children, as it did help attract help from certain NGOs and pre-eminent ministries working for the children's welfare.

\section{Politics and Policy Stream}

Kingdon's (1995) argues that politics should be seen as part of the policy process, rather than in isolation. He further proposed three key elements that influence the political survival of the chosen policy. He identified that when a problem is discussed and is acknowledged widely, various policymakers step into action and various policy communities develop around specific domains and even specific problems.

In 2010 the National Commission for Protection of Child Rights had set up a 19 member working group to investigate the issue of safe guarding the rights of children at railway platforms, they held several meetings with representatives the railway administration, RPF, Government Railway Police Force (GRP) and civil society organisations. One of main suggestions made by them was to establish linkages between the Juvenile Justice (JJ) Act and the Railways Act/RPF Act. According to the Juvenile Justice Act 2000 (Amendment 2015), a 'delinquent juvenile 'is a child who is in conflict with the law while a 'neglected juvenile 'is a being who is abused or there is a possibility that he/she may be abused in the future, these juveniles are brought before the Juvenile court and Juvenile Welfare Board respectively. According to JJ Act a child could be tried as an adult if he or she has committed a heinous offence ( a heinous offence has a minimum punishment of at least 7 years) (Bajpai, 2006 ). 


\section{International Journal of Social Science and Economic Research}

ISSN: 2455-8834

Volume:05, Issue:10 "October 2020"

The Child Labour (Prohibition and Regulation) Act of 1986 illegalizes the presence of self employed children working at railway platforms. At the same, under the Indian Railway Act of 1989, children travelling on trains with no tickets can be charged as 'delinquents', and under the still active Indian Penal Code of 1860 even a 8 year old can be charged as an adult. These existing laws makes the 'Railway children 'delinquents or criminals and nulls the requirement to provide 'care and protection'. The NCPCR made the suggestion that the railway ministry must acknowledge the JJ Act, and even if a child is found in conflict with the law and is an illegal passenger, he/she must be treated as a child first.

According to individual X in 2013 a particular landmark ruling by the New Delhi High court had paved the way for streaming the involvement and support of railway administration across the country in huge way (Interview). This case was Khushboo Jain (Petitioner) vs The Ministry of Railways (see Jain V.K, 2013). Some of the important prayers made by the petitioner in her petition was the creation of a) Child Shelter booths along the lines of 'Muktangan 'for boys and girls to provide support and shelter b) Creation of Chid welfare committees operating under the JJ Act 2000. The verdict of the court had placed Railways at the pinnacle for creating a safe environment for the child arriving at the platform. By December 2013, acknowledging the seriousness of the issue and following the directions of the High Court of Delhi, Ministry of Railways with the support of Ministry of Women and Child Development and NCPCR, the Governing Board of the Indian Railways formulated and issued a 'Standard Operating Procedure (SOP) on Protection of Rights of Children at Railway Stations over Indian Railways'. However this was superseded by a revised SOP provided by the Ministry of Women and Child Development (MWCD) on March 2015. (Chairman Letter, n.d; The Pioneer, 2015).

By 2015, Maneka Sanjay Gandhi, the Union Minister for MWCD had joined hands with the Railways in a partnership to combat the problem. Both the ministries signed memorandum of understanding on issues concerning the rescue of vagrant and abducted children from railway stations. A massive awareness campaign to inform the stakeholders especially the secondary stakeholders such as the passengers, the porters and all non railways employees present on the platforms, this was planned with printing of posters which were to be pasted around the station and inside the coaches, jingles and slogans would be played through public address systems throughout all stations. (Ohri, 2015). Training of all main stakeholders working on the platform through various workshops throughout the year.

In 2016, a three day event was held in the capital of the country with the SAARC countries to discuss the partnership on protection of children. The Union Home Minister, Rajnath Singh expressed his disposition to work towards bringing protection of children in the subsequent agenda, 'in terms of strengthening the institutional and coordination mechanisms and to develop 


\section{International Journal of Social Science and Economic Research}

ISSN: $2455-8834$

Volume:05, Issue:10 "October 2020"

a regional strategy that defines clear milestones towards the realization of the Sustainable Development Goals(SDGs). '(South Asian Government News, 2016).

In August 2017, the district government of Jashpur, Chhattisgarh initiated a pilot program to provide ten female trafficking survivors a location and equipment to open a bakery. Similarly, The Railway Children has started employing street children as 'peer workers 'at various child help desks operated by them at the stations. As children are often reserved and frightened by adults and especially the RPF or the police due to their uniforms (Interview 1, Steinberg, 2012). These peer workers understand the situation better faced by these runaway children . They help in patrolling the stations and help in identifying and interacting with runaway children arriving at stations, thereby making them feel comfortable and safe in opening up to discuss their problems. (Railway Children, 2014).

On the 15th of November 2018, the Chairman of Railway Board, Mr. Ashwani Lohani, had asked the Zonal Railways to spread awareness across the entire Railway system to sensitize all the Railway officials, passengers and secondary stake-holders on the issue of providing care and protection to children coming in contact with Railways. In this regard a booklet developed by National Commission for Protection for Child Rights (NCPCR) titled as "Guide Book for Creating a Child Friendly and Protective Environment for Children in Contact with Railways was prepared for the guidance of Railways. An organisation called the Railway Children India (RCI) is a partner organization of National Commission for Protection for Child Rights (NCPCR). In the year 2009, the RCI had published a series of steps on combating the increasing number of runaway and street children coming in contact with the railway officials. Steps included in their suggestions involved building short stay shelters on the railway platforms, training of RPF and the GRP officials. The RCI has recently developed a 3.5 hours training module in the context of Railway's Standard Operating Procedure., which involves imparting training for Railway Officials on Child Rights and Child Protection and related Laws which are to be utilized as course curriculum for the 3.5 hours training modules on child safety. (Chairman Letter, 2018). This is being included as part of course curriculum in all Training Programs ( during initial/ refresher/ promotional courses) to Railway Staff (especially TTEs, RPF \& Station Masters) in the Zonal Training Centres, Workshops for creating awareness and sensitization of frontline staff such as Station Masters, Ticket Checkers, Porters etc. were also held in the 6 cities.

Knill and Tosun (2015) explain how interest group influence is not only a matter of resources, but also the access they have with the issue due to ties with the politicians and bureaucracy. Interest groups such as RCI have the necessary resources and skills to effectively deal with the problem and able to provide valuable insights to the policy and at the same time 


\section{International Journal of Social Science and Economic Research}

ISSN: $2455-8834$

Volume:05, Issue:10 "October 2020"

The MoU has been executed between the Railway Women Welfare Central Organization, (RWWCO), registered under Cooperative Societies Act, 1912, the RWWCO is the apex body of the chain of Women's Welfare Organizations spread across all zones of Indian Railways, engaged in the task of welfare of Railwaymen/ women and their families and Prayas JAC Society, a national level, non-profit, child centric organization, which is also a registered society under the Society Registration Act, also registered with 'DARPAN PORTAL of NITI AAYOG'. The organization has been working with the marginalized, vulnerable, distressed, deprived, destitutes and also with children coming in contact with Railways from past three decades through multiple programs such as child protection, juvenile justice, emergency helpline number for distressed children (CHILDLINE 1098), running children home/ shelters as 'fit institution', education, nutrition, health, vocational training \& life skill programs. The organization has 46 Homes/Shelters for children, women \& adults including emergency helpline number (CHILDLINE-1098) and is supported by the Ministry of Women \& Child Development, CHILDLINE INDIA FOUNDATION/ State Governments etc in 09 States/UTs, namely Delhi, Bihar, Jharkhand, Gujarat, Assam, Arunachal Pradesh, Haryana, Andaman \& Nicobar Islands and Rajasthan.The organization is presently controlled and managed by the 25 member Governing Body of Eminent persons.

The Agreement are being executed between the Railway Women Welfare Organization and Prayas JAC Society to set up Open Shelters and Child Help Desks, (CHD) on pilot basis at the following six railway stations, namely, Delhi, Ahmedabad, Jaipur, Danapur, Samastipur and Guwahati for care and protection of vulnerable and distressed children coming in contact with the Railways.

The Railway Board directed the concerned General Managers of the Zonal Railways regarding 'Pilot for setting up of Open Shelters 'for its implementation and to ensure care and protection to large number of distressed, runaway, separated, trafficked and vulnerable children at the Railway Station or near the areas surrounding the Railway Station. The Open Shelter will be run on $24 \times 7$ hour's basis and would provide basic services such as nutrition, psycho-social support, and medical aid etc. It will be used as transit in restoring the children with their families by following the laid down process under Juvenile Justice (Care \& Protection of Children) Act, 2015.

The Open Shelter are being be set up at one of the Platforms at all the six Railway stations for providing care \& protection to vulnerable children coming in contact with Railways, RPF \& GRP,(Railway Protection Force \& Government railway Police ), child helpline/CHD and others concerned at the Railway Stations or at any place adjacent to the railway station. 


\section{International Journal of Social Science and Economic Research}

ISSN: $2455-8834$

Volume:05, Issue:10 "October 2020"

These Shelters are of approx 2000 square feet of accommodation which accommodates 25 children and provides immediate relief to them by way of providing basic services, such as, nutrition, psycho-social support, medical aid and would be used as a transit in restoring the children with their families by following laid down process in Juvenile Justice (Care \& Protection of Children) Act 2015 \& Model Rules, 2016. Each Shelter is segregated into the following: Dormitory-(1000 square feet), 2 Bathrooms (25 square feet each), person-in-charge room/counselling room/office room (500 square feet) and one store room (125 square feet). The Railway authorities are providing space for setting up Open Shelter and also space for setting up Childline (1098) which functions as Child Help Desk, (CHDs) to Prayas JAC Society. One care taker has been provided by RWWO through the concerned Railway Division to guard the property and look after the assets.

All the operational expenditure required for running the Open Shelter and of running the Child Help Desks are being provided by the Prayas JAC Society. Day to day petty maintenance of the building and electricity and water will be provided by concerned Railways. However, charges for water and electricity consumed are to be paid by Prayas JAC Society to the Railways.

The Prayas JAC Society should have valid registration or recognition certificate of 'FIT INSTITUTION', duly declared under the Juvenile Justice (Care \& Protection of Children) Act 2000/2006/2015. The Open Shelters will become operational after all necessary clearances and licenses have been obtained by the 'Prayas JAC Society 'from concerned Governments and will remain operational during the validity of these clearances/licenses. Responsibility of running the Open Shelter would be that of Prayas JAC Society. Any legal matters arising out of running of Open Shelters and its settlement including expenditure thereof shall be sole responsibility of Prayas JAC Society. RWWO will be completely indemnified from such disputes/legal matters and any expenditure thereof.

Further, in terms of Railway Board directives apart from the mechanism set up by MWCD and respective State Governments for ensuring proper running of the shelter as per law by Prayas JAC Society, an 'Oversight Committee 'are being set up by the concerned Divisional Railway Manager (DRM) these would keep an oversight to ensure optimum standards of care and protection at the Shelter/CHDs. The Women Welfare Organisations and Prayas JAC society would have representatives on this Oversight Committee apart from Members of Child Welfare Committee (CWC), District Child Protection Unit (DCPU), concerned Station Master/Station Superintendent, concerned RPF Post In charge, concerned Inspector GRP, Assistant Personnel officer (APO) and Assistant Engineer (AEN). The MOU will be governed by Railway Board's directives. The allotment of accommodation has been done initially for a period of 5 years, extendable by another 5 years at the end of first 5 years. Overall we could see various ideas and 


\section{International Journal of Social Science and Economic Research}

ISSN: $2455-8834$

Volume:05, Issue:10 "October 2020"

policies being generated for the problems which were emerging due to various different reasons. There was a primeval soup of policy solutions afloat.

\section{Discussion}

The MSA provides a good framework to explain how Railways child protection policy came onto the agenda. Although there are various shortcomings in the framework, from the interviews it was pointed out that the Railways was always concerned about the welfare of runaway children. Even before the SOP was rolled out we could notice a 'little window 'of opportunity being opened up, where the individual efforts of one bureaucrat (individual X) were noticed by the higher authorities of the Indian Railways. Kingdon (2003) posits that 'problems by themselves can structure governmental agenda', however the chances of an item rising on the agenda rises dramatically if all the three streams are coupled together (p. 178).

It can be posit that initially the realisation of the problem stream back in 2001 had an effect on the local government agenda which is the Railways in this case and a 'little window of opportunity 'had opened up at the local level, where only the Railway ministry along with a few non government organisations were involved in solving the problem. At this point of time it was easier to identify the policy entrepreneur, which in this case were the bureaucrats Individual $\mathrm{X}$ and Mr. Pandey, who had decided to replicate the Malda model of child protection after seeing its success throughout the country's stations.

Kingdon's MSA helps to understand why issues do or do not achieve political salience as it helps to understand the influence of the various agenda setters such as the politicians, bureaucrats, interest groups, media groups etc. In his book he has given special importance to elected officials and politicians in the agenda setting, formulation and implementation of public policies. He says that "If any one set of participants in the policy process is important in shaping of the agenda, it is elected officials and their appointees, rather than career bureaucrat or non governmental actors" (pg.17). His research did not find career bureaucrats as influential in agenda setting, respondents in his interviews have been quoted saying that civil servantsoften keep beating around the bush, thereby delaying or halting the decision making process altogether. However it is to be noted that the context in his case study revolved around the policies involving health and transportation in the United State's federal government, which had garnered quite a momentum in Capitol Hill. The formulation and decision making power rested in the hands of elected officials rather than the bureaucrats.

In our case study, social policies like those based on child protection are topics which are generally not advocated by politicians in their election speeches or assembly speeches due to the complexity of the issue or less popularity amongst the masses. In a developing country such as 


\section{International Journal of Social Science and Economic Research}

ISSN: $2455-8834$

Volume:05, Issue:10 "October 2020"

India, social issues related to the environment, child protection, liberal education are rarely on the agendas of the political parties. If we take a gander at the 2019 election manifesto of the current majority ruling party in India - The BJP, the policies on child protection are nearly non existential; with just a few lines dedicated for implementation of a Child protection framework, which seems as a vague and non explanatory term. (See, BJP Manifesto 2019, p.35). Schnapp (2000) explains how bureaucrats become 'stand-in 'agenda setters in situations where politicians do not have technical knowledge or the time to set the agenda.

After conducting the interviews with the two senior officials of the RPF, the question "Was there any political involvement for the topic to appear on the agenda?" Had a stern resounding reply of 'No'.

The MSA had failed to acknowledge the role of bureaucrats.

It is worth noticing that even the problem definition at the beginning was limited to reuniting the runaway children with their families. Weber \& Rittel (1973) explains that one of the most intractable problems with wicked problems is defining them. The involvement of various actors and their resources also depends upon this problem definition. With numerous cases of human trafficking merging through the years, various ministries pinpointed the source of the problem emitting due to lack of security and support for children at the railway stations. This in turn lead to the problem definition being to rehabilitate runaway children as well as incorporating human trafficking.

As soon as the scope/field of problem definition was increased, there was intergovernmental cooperation amongst three ministries to deal with the problem along with community and non government organisation assistance. The SOP was a means to rehabilitate and reunite the runaway children with their families at the same time it was a means to fight human trafficking going unchecked at the railway stations.

\section{Policy Entrepreneur}

The turnabout in the case study came with the court ruling in the year 2013. Kingdon (1995) posits that policy entrepreneurs are able to recombine alternatives and couple proposal concepts together. In doing so, their success depends on access, resources, and strategies. These policy entrepreneurs must be present at the correct place at the correct time when the policy window is open. Khushboo Jain can be seen as an outright policy entrepreneur who using her resources approached the judicial power. Khushboo Jain, an academic researcher currently turned activist, had witnessed the death of child on the Railway platforms back in 2011 while working on her research - why do children run way from home. Her PIL (Public Interest Litigation) filed in that year demanded a system that cares for children in distress and assists them without procedural 


\section{International Journal of Social Science and Economic Research}

ISSN: 2455-8834

Volume:05, Issue:10 "October 2020"

hassle. While such a set of guidelines had existed on paper as formulated by the NCPCR, nothing was being done to implement it. The court ruling finally pressurised the government to implement this system.

\section{Opening Window of opportunity}

As discussed above, even before the court ruling of 2013, there was work carried out by the Railway at the local level which was well appreciated by the media; local and international. Kingdon says that these windows stay open for a short while and are unpredictable. Analysing the entire scenario, it is possible to say that from 2010 to 2013 was the time when the 'Big window 'of opportunity opened up. However during this time the relationship between the problem and policy stream was consequential. It is safe to say that after the little window of opportunity, the situation changed as the issue started gaining more prominence, especially since a new problem captured the attention of government officials and those close them, this situation was trafficking. One of the main reason why many at times issues reach an agenda is due to a situation of a particular circumstance. In the case of the platform children, the situation can be described according to the term fashionable as coined by Hogwood and Gunn (1984), which can defined as an "issue which is difficult to explain but easy to recognise." In our case, problems related to the runaway children was linked with increase in perchance of human trafficking, drug abuse amongst minors, prostitution, thefts and other forms of street crimes. Besides this the social policy issues like this often strike a cord with their "human interest angle" or emotive aspect thereby coming into the media's limelight. However such circumstances do not guarantee politicisation and access to the public policy agenda. Since the problem is defined as a wicked issue, there was no preset template which was being followed to solve the problem. Teams that solve wicked problem must make things up along as they proceed forward. In response to this problem, the NCPCR set up various guidelines and were often guided by various interest groups and ministries working in response to the problem this helped activate the policy stream. However the policy stream still continued to remain open even after 2013, as ideas and mitigation measures were still being generated to reduce the problem. It is hard to ascertain whether any major political parties were involved during this period, however after the ruling of the high court was passed in the year 2013, there are some instances where we can see involvement of politicians in promoting and spreading awareness about the policy. The politics stream was opened with the involvement of pressure groups such as the Railway Children, Muktangan and activist Khushboo Jain along with the involvement of bureaucrats, which helped to bring the agenda at the forefront. This was coupled with judicial intervention which further pressurised the government to take action. In the authors knowledge there has not been any case study where the judicial system helped the policy entrepreneurs in furthering an agenda, the importance of the judicial system is underrepresented in Kingdon's model. Therefore all three 


\section{International Journal of Social Science and Economic Research}

ISSN: $2455-8834$

Volume:05, Issue:10 "October 2020"

streams opened up allowing the judicial system to place child protection for children at the railway stations on the government's agenda. Hence this short duration of the open window lends powerful credence to the old saying. "Strike while the iron is hot".

\section{Further Evaluations}

The situation for the runaway and trafficked children is improving relatively each year. However there is still a shortage of data and information pertaining to issues related to child protection according to the Ministry of Women and Child development. There is a need to implement better data collection especially at railway stations which can serve as indicators for future policy makers. Since most of the runaway children problems stem due to family issues, it is important to tackle the problem at the roots, which involves focusing on the parents by instilling values of Good parenting, which helps make family life a priority and create a balance between relationships within the family and activities outside the family. Besides the existing Child trafficking schemes there are not enough homes for trafficked victims and there are fewer shelters compared to the magnitude of the problem (Chopra, 2015). Similarly, state interventions to rescue and reintegrate children trafficked for labour exploitation have not been carefully evaluated (Donger \& Bhabha, 2018). Special focus should be made to improve the state policies on prevention of trafficking.

\section{Conclusion}

In summary it can be said that Kingdon's theory of multiple streams does capture the process on how the issue of child protection at Railway stations came onto the Government's agenda, to an extent and provides a reliable and sufficient framework.

The analysis of the problems stream revealed that feedback channels such as the media helped shed light on the work being carried out by the Railway ministry. This helped in attracting various interest groups which thereby helped in the providing viable solutions in the policy stream. With the involvement of various ministries, bureaucrats stepped in as the agenda setters. In the politics stream, the pressure by the interest groups and judicial ruling coupled with problem stream helped open a policy window which was used successfully by a policy entrepreneur. Hence all three streams helped bring the topic on the government's agenda. Though the problem of runaway and trafficked children had existed for a quite a while, it was a situation of 'Schrodinger's cat', where people couldn't analyse the problem and formulate solutions until the time they actually opened the box. The essay argues that to an extent the MSA provides a reliable and sufficient framework to explain agenda setting in a developing country, however further research is needed into the role of bureaucrats as agenda setters and how local government's 'little windows 'can act as catalysts to open the 'big windows'. 


\section{International Journal of Social Science and Economic Research}

ISSN: $2455-8834$

Volume:05, Issue:10 "October 2020"

The emergent need for an effective roadmap is necessary to address the multidimensional issues prevalent in the given scenario. The onerous task of a multidisciplinary approach by active participation of all the key stake holders in the varied social, political, economic, geographic and cultural environments is a challenging task. In summation, the need for further research on creation and functioning of Joint Action Committees having access to a data base which leverages technology, networks, integrates and generates live actionable data that can be shared, analysed and interpreted to create actionable inputs for the key stakeholders still remains.

\section{References}

Bajpai, Asha (2006) Juvenile Justice: Administration and Implementation. In Child Rights in India: Law, Policy, and Practice. 2nd ed. Delhi: Oxford University Press, 2006. Oxford Scholarship Online [Online] Available from: doi: 10.1093/acprof:oso/9780195670820.001.0001. [Accessed 1 August 2019].

BJP Manifesto (2019) Party Manifesto [Online] Available from: http:// www.documentcloud.org/documents/5798075-Bjp-Election-2019-Manifesto- English.html [Accessed 10 August 2019].

Brunner, S.(2008) Understanding policy change: Multiple streams and emissions trading in Germany, Global Environmental Change, 18(2008),501-507. Available from: York Online Library [Accessed 18 August 2008].

Cairney, P (2011) Understanding Public Policy : Theories and Issues, Palgrave Macmillan, Basingstoke. Available from: ProQuest Ebook Central. [1 August 2019].

Cairney, P. \& Zahariadis, N. (2016) Multiple streams analysis: A flexible metaphor presents an opportunity to operationalize agenda setting processes, Handbook of Public Policy AgendaSetting. Available from: https://paulcairney.files.wordpress.com/2013/10/cairney-zahariadismultiple- streams-2016.pdf [Accessed 15 August 2019].

Chairman Letter (2018) Care and Protection of children in contact with the Railways [Unpublished].

Chopra, G 2015, Child Rights in India : Challenges and Social Action, Springer, New Delhi. Available from: ProQuest Ebook Central. [18 August 2019].

Clarke, M. and J. Stewart. (1997) Handling the wicked issues. A Challenge for Government. Birmingham: INLO- GOV . 
International Journal of Social Science and Economic Research

ISSN: 2455-8834

Volume:05, Issue:10 "October 2020"

Cohen, M., March, J. and Olsen, J. (1972) 'A Garbage Can Model of Organizational Choice’, Administrative Science Quarterly, 17, pp.1-25

Demers, L. and V. Lemieux. (1998) 'La politique que' be' coise de de' sengorgement des urgences', Canadian Public Administration, 41(4), 501-28.

Donger,E. \& Bhabha,J. (2018) Dilemmas in Rescue and Reintegration: A critical assessment of India's policies for children trafficked for labour exploitation. [Online] Available from: DOI: 10.14197/atr.201218104 [Accessed 30 July 2019].

Exworthy, M. et al (2002) How Great Expectations in Westminster May Be Dashed Locally: The Local Implementation of National Policy on Health Inequalities, Policy and Politics, 30(1), 7996. Available from: Google Scholar [Accessed 10 August 2019].

Exworthy, M. et al (2004). 'Big Windows and Little Windows: Implementation in the "Congested State", , Public Administration, 82(2), 263-81.Available from: Google Scholar [Accessed 10 August 2019].

Faleiro, S.(2017) Why Do So Many Indian Children Go Missing? [Online] Available from: https://www.nytimes.com/2017/11/19/opinion/missing-children-india.html [Accessed 4 August 2019].

Gupta, Jayant (2011) Childhood lost on railway platforms [Online] Available from: Nexis [Accessed 2 August 2019].

Hogwood,W.B and Gunn, A.L (1984) Policy Analysis for the Real World, New York,Oxford University Press.

Howlett, M, and Ramesh, M (1995) Studying Public Policy. Toronto: Oxford,University Press

Indian Government News (2017) Railway Protection Force to implement its Child Rescue Campaign in 47 additional Railway Stations taking total to 82 Railway Stations [Online] Available from: Nexis [Accessed 13 August 2019].

International Labour Organisation (2017) Fact Sheet: Child Labour in India [Online] Available from: https://www.ilo.org/newdelhi/whatwedo/publications/ WCMS_557089/lang--en/index.htm [Accessed 5 August 2019].

Jain, V.K. (2013) Khushboo Jain vs Ministry Of Railways [Online] Available from: https://indiankanoon.org/doc/24157251/ [Accessed 2 August 2019]. 
International Journal of Social Science and Economic Research

ISSN: 2455-8834

Volume:05, Issue:10 "October 2020"

Khan, Hamza (2015) Lifeline Mughalsarai: Tracking life and change at the station on India's busiest railway route [Online] Available from: Nexis [Accessed 3 August 2019].

Knill, C. \& Tosun, J. (2012) Public Policy: A New Introduction, London, Palgrave Macmillan.

Kingdon, J. (1984; 1995). Agendas, Alternatives and Public Policies (1st and 2nd eds.), New York, NY: Harper Collins.

Kingdon, W.J (2003), Agendas, Alternatives, and Public Policies. Second edition. United States, Addison-Wesley Educational Publishers Inc.

Livemint (2017) Nithari killings: A timeline of the case so far [Online] Available from: https://www.livemint.com/Politics/W3UVdT8AW4j8TLrlX1sElI/Nithari- serial-killings-Atimeline-of-the-case-so-far.html [Accessed 7 August 2019].

Mathur, Meena (2009) Socialisation of Street Children in India: A Socio-economic Profile, Psychology and Developing Societies, 21(2): 299-325 [Online]Available from: DOI:

10.1177/097133360902100207 [Accessed 2 August 2019].

McMillin, S.E. (2014) Healthy Families and Gay Rights: A Multiple Streams Analysis of Civil Union Legislation in Illinois, The Journal of Contemporary Social Services.

Mintrom, M. \& Norman,P. (2009) Policy Entrepreneurship and Policy Change,Policy Studies Journal, 37: 649-667. Available from: doi:10.1111/j.1541-0072.2009.00329.x [Accessed 15 August 2019].

Mishra, Prachi (2015) Report Summary: Report of the Committee for Restructuring of Railway Ministry and Railway Board [Online] Available from: Nexis [Accessed 14 August 2019].

Nair,P.M. (2003) A Report on Trafficking in Women and Children in India 2002-2003 [Online] Available from: http://nlrd.org/wp-content/uploads/2012/02/ ReportonTrafficking.pdf [Accessed 1 August 2019].

National Records Crime Bureau (2016) Crime in India 2016 Statistics [Online] Available from: http://ncrb.gov.in [Accessed 17 August 2019].

Ohri, R. (2015) Ministries come together to curb child trafficking at railway stations [Online] Available from: Nexis [Accessed 30 July 2019]. 
International Journal of Social Science and Economic Research

ISSN: 2455-8834

Volume:05, Issue:10 "October 2020"

Pagare, D et al. (2004). Risk factors of substance use among street children from Delhi. Indian Pediatrics, 41, March issue, 221-225 [Online] Available from: https://

www.indianpediatrics.net/mar2004/mar-221-225.htm [Accessed 31 July 2019].

Powell, M., Exworthy, M. and Berney, L. (2001) 'Playing the game of partnership', in R. Sykes, C. Bochel and N. Ellison (eds) Social Policy Review 13: Developments and debates: 2000-2001, Bristol: The Policy Press.

Railway Children (2014) Child Friendly Stations in India [Video] Available from: https://www.youtube.com/watch?v=SZvokDa9AkU [Accessed 1 August 2019].

Raval, V.V. et al (2010) Damned if They Flee, Doomed if They Don't: Narratives of Runaway Adolescent Females from Rural India, J Fam Viol, 25, 755-764 [Online] Available from: DOI: 10.1007/s10896-010-9333-5 [Accessed 1 August 2019].

Ridde, V. (2002) Policy Implementation in an African State: An Extension of Kingdon's Multiple-Streams Approach.Public Administration Vol. 87, No. 4, 2009 938-954, Blackwell Publishing Ltd. Available from: DOI: 10.1111/j. 1467-9299.2009.01792.x [Accessed 18 August 2019].

Roy, Avik (2016) Children of a lesser god [Online] Available from: Nexis [Accessed 3 August 2019].

Schnapp,K.U (2000) Ministerial Bureaucracies as Stand-In Agenda Setters ? A Comparative Description, WZB Discussion Paper, FS III 00-24. [Online] Available from:

https://www.econstor.eu/bitstream/10419/49000/1/320288617.pdf [Accessed 6 August 2019].

Soroka , S. (2002) Agenda-Setting Dynamics in Canada, Vancouver, University of British Columbia Press.

South Asian Government News (2016) Dynamic measures undertaken by Railway protection force to come upto the expectations of the travelling public for a safer travel during year 201516 [Online] Available from: Nexis [Accessed 12 August 2019].

Steinberg, J. (2012) Runaway Train: Railway Children and Normative Spatialities in India [Online] Available from: http://www.uvm.edu/ jsteinbe/RunawayTrain.pdf [Accessed 1 August 2019].

The Economic Times (2015) Indian Railways: 10 transformative recommendations of Bibek Debroy Committee report [Online] Available from: Nexis [Accessed 18 August 2019]. 
International Journal of Social Science and Economic Research

ISSN: 2455-8834

Volume:05, Issue:10 "October 2020"

The Pioneer (2015) Railways for children [Online] Available from: Nexis [Accessed 6 August 2019].

Townsend Mark (2017) The scandal of the missing children abducted from India's railway stations [Online] Available from: https://www.theguardian.com/globaldevelopment/2017/jul/30/global-development-india-child-trafficking [Accessed 17 August 2019].

United States Department of State (2018) 2018 Trafficking in Persons Report [Online] Available from: https://www.refworld.org/docid/5b3e0blea.html [Accessed 3 August 2019].

UNODC (2018) Global Report on Trafficking in Persons [Online] Available from: https://www.unodc.org/documents/data-and-analysis/glotip/2018/

GLOTiP_2018_BOOK_web_small.pdf [Accessed 4 August 2019].

Vital1 (2014) Railway children in Kolkata [Video] Available from: https:// www.youtube.com/watch?v=zrjxSzY7Pmg [Accessed 2 August 2019].

Weber, M.M. \& Rittel, W.J.H (1973) Dilemmas in a General Theory of Planning,

Policy Sciences, 155-169. [Online] Available from:

https://link.springer.com/article/10.1007/BF01405730 [Accessed 30 July 2019].

White, A. (2015) The politics of police 'privatization': A multiple streams approach. Criminology and Criminal Justice, 15(3),283-299. Available from: York Online Library [Accessed 18 August 2019].

Zahariadas, N. and Travis, R. (2002) A Multiple Streams Model of U.S Foreign Aid Policy. Policy Study Journal, 30(4), 495-514. Available from: York Online Library [Accessed 17 August 2019].

Zahariadas (2003). Ambiguity and Choice in Public Policy: Political Manipulation in Democratic Societies. Washington, DC: Georgetown University Press. 